$\xi=-1$

\title{
Rescuing Asylum-Seeker Stranded at Sea: Malaysia's Duty under International Law
}

\author{
Syafiq Sulaiman ${ }^{1 *}$, Salawati Mat Basir ${ }^{1}$, Mohd Zamre Mohd Zahir ${ }^{1}$ \\ ${ }^{1}$ Faculty of Law, Universiti Kebangsaan Malaysia \\ *Corresponding author E-mail: sfiq@siswa.ukm.edu.my
}

\begin{abstract}
The protection of the right to life and the duty to rescue persons in distress at sea are the fundamental obligations under two specialized international law regimes which are the international human rights law and the law of the sea. These rules when read together form a strong protection of the human rights of the asylum-seekers stranded at sea. However, often states failed to honour this obligation for various reasons ranging from national security to economic reasons. This article will analyse Malaysia's responsibilities as regards the right to life and the duty to rescue of these asylum-seekers. It will also identify the existing international and domestic legal framework relevant to the application of these obligations upon Malaysia and whether it has acted in breach of such obligations. The article then proceeded with suggestions for further improvement that Malaysia can adopt in order to better perform its obligations. This study is a pure doctrinal legal research which is qualitative in nature. The data used in this research is collected from library-based resources. These data were then analyzed by using methods of content analysis as well as critical analysis. The article found that Malaysia has a duty to protect the right to life under international human rights law. Additionally, Malaysia is also bound under the law of the sea to perform its duty to rescue. In view of Malaysia's failure to perform these duties in two occasions in the past consequently had resulted in a violation of international law. Therefore, it is suggested that Malaysia should initiate a revision of its national laws and policies regarding treatment of asylum-seekers stranded at sea to be in line with Malaysia's duty under international law. Besides, the Malaysian Maritime Enforcement Agency is call upon to comply with the international standards of treatment of persons in distress at sea which includes the asylum-seekers.
\end{abstract}

Keywords: Asylum-Seeker, Duty to Rescue, International Law, Malaysia, Right to Life.

\section{Introduction}

Asylum-seeker is a status which is associated with uncertainty and legal limbo. Eventhough by virtue of the United Nations High Commissioner for Refugees's position that an asylum- seeker is actually a refugee as long as he fulfils all the criteria set out in the main Convention Relating to the Status of Refugees 1951, its additional Protocols or a few other treaties that can grant such status under international law. The recognition as a refugee is merely a confirmation of that person's status, it does not however establish it. Therefore, the fact that an asylum-seeker is not yet formally recognized as a refugee does not exclude him from the protection exist under the refugee law framework such as the rule on nonrefoulement. Besides, the fact that the asylum-seekers are also human beings, it thus entitled them to the protection of their fundamental human rights such as the right to life without any discrimination.

According to the UNHCR, asylum-seekers are those individuals who have sought international protection and whose claims for refugee status have not yet been determined, irrespective of when they may have been lodged [1]. This is in contrast with the definition of refugee which includes either individual recognised under the 1951 Convention relating to the Status of Refugees. its 1967 Protocol, the 1969 OAU Convention Governing the Specific Aspects of Refugee Problems in Africa, those recognised in accordance with the UNHCR Statute or those individuals who are grant- ed complementary forms of protection or enjoying temporary protection [2].

\subsection{The Plight of Unreached Asylum-Seeker on Malay- sian Water}

Malaysia's treatment of asylum-seekers who arrived in the country via sea routes was a mixed of two extremes. At one side of the spectrum, it received them with almost unequivocal acceptance, while on the other side, an outright rejection. But one thing that is clear, is that such acceptance is never based on human rights, but it was due to humanitarian contemplation on the part of the government. Historically, the arrival of asylum-seekers in Malaysia began back in 1970s with the incoming of large groups of Filipino fleeing the southern Philippines after a major fight broke out [3]. These asylum-seekers were allowed entry into the country without much resistance from Malaysia. In contrast however, in early 1990s, the Malaysian government had towed boats of Vietnamese asylum-seekers back to the sea under the order of the former premier, Mahathir Mohamad [4]. He justified this action on the ground of "preventing foreign vessels from entering [Malaysian] waters" and to protect local fishermen from intrusion from foreign fishermen boats.

Regrettably, the history has repeated itself, as recently in 2015, the Malaysian authority decided to adopt the push-back policy by pushing away boats that were carrying asylum-seekers of Rohingya's ethnicity which is one of the world's most persecuted people back to the open sea. In the words of the first admiral of Malay- 
sia's maritime enforcement agency, Tan Kok Kwee: “[w]e won't let any foreign boats come in". In case of the boats are sinking, he said that his agency will only provide "provisions and send them away". Such harsh treatment was echoed in the statement made by the then Malaysian Deputy Home Minister, Wan Junaidi Tuanku Jaafar that "[w]e are sending them the right signal, to send them to where they came from".

This very policy which has been by committed other countries in the past, such as Australia and Italy had be reprimanded by many international organizations as well as scholars of international as an act that is inconsistent with the established rules of international law [5]. The United Nations Refugee Agency issued a press released expressing its concerns regarding the well-being of these asylum-seekers and the way the Malaysian authority being indifference to the plight of one of the most prosecuted human beings in the world. [6] Human rights advocates such as the Human Rights Watch calling an end to the pushback of boats in the Malaysian waters [7].

\subsection{Current Development}

This harsh treatment, however, has changed as of late. Malaysian government is now in a more assistive mood by helping these asylum seekers and disembark them on its shores [8]. According to the current statistics provided by the UNHCR, there are currently 56,311 asylum-seekers living in this country which is the highest among all ASEAN countries. The author would like to note that this treatment is motivated by humanitarian concerns, rather than consideration of legal obligation on the part of Malaysia [9] Due to this reason, the author feels rather cautious with the government's move and the purpose of this article is to highlight Malaysia's legal responsibility under international law to protect these asylum seekers not on the ground of humanitarian alone, but also on the ground of established rules of law.

This article will address some of the legal aspects of the obligation to protect the right to life of the asylum-seekers at sea and how it relates to the duty to rescue under international and Malaysian laws. The thesis underlying this article is that an asylum-seeker has the right to life. Since he is entitled to the protection of his life, the corollary of this notion requires Malaysia to exercise her duty to rescue him which will uphold his right to life. Failure on the part of Malaysia will violate this established rule of law and exposing Malaysia to an international responsibility.

\section{Research Design and Method of Analysis}

The authors approach the analysis in this article through a doctrinal legal research, which is a qualitative study with an objective to find Malaysia's duty under international law to rescue asylumseekers stranded at sea. The materials for analysis are found from multiple sources in international and local literature. These sources are gathered from both primary and secondary data. These include primary data such as treaties, conventions and international agreements, as well as the Malaysian law statutes. Whereas, the secondary data include materials such as books, journal articles, newspaper reports, reports by international agencies, law reports and others. These data were then analyzed by using methods of content analysis and critical analysis.

\subsection{The Right to Life}

International law acknowledges every individual's right to seek asylum. As seeking asylum and migrating from one's own country for the purpose of safety is allowed, international law prohibits states from penalizing those who enter the states boundaries for the sake of seeking the asylum. As asylum seekers are also human beings, they also have the right to life. The right to life is 'inherent'. It means that this right flows from the fact of being a human. States should not just see this principle in negative views of pro- hibiting states from some actions such as "to kill", "to inflict fatal harm", but also in the context of this writing, in the positive views which are to save the asylum-seekers in needs and not to push away the asylum seekers stranded on the seas without help. International law prohibits countries from returning asylum seekers back to danger. International law has been very critical regarding protecting the right to life. This is evident in huge numbers of international conventions and covenants that emphasized greatly on this principle.

The right to life is the very basis of all human rights accorded to every human being without any discrimination as to race, religion, political opinion, nationality, country of origin or physical incapacity. The Charter of the United Nations, in its Preamble stated that "the Peoples of the United Nations Determined to reaffirm faith in fundamental human rights, in the dignity and worth of the human person". The protection of the right to life has been incorporated in various international conventions and agreements of global or regional standing. This includes the European Convention on Human Rights (Article 2); the Convention on the Rights of the Child (Article 6); the International Convention on the Protection of the Rights of All Migrant Workers and Members of Their Families (Article 11); the Convention on the Rights of Persons with Disabilities (Article 10); the African Charter on Human and Peoples' Rights (Article 4); the American Convention on Human Rights (Article 4); Convention Relating to the Status of Refugees (Article 33).

Article 14 (1), Universal Declaration of Human Rights (UDHR) provides for the right to seek asylum. It states that "[e]veryone has the right to seek and to enjoy in other countries asylum from persecution." This soft law is now considered as part of customary international law [10]. The right to seek asylum is therefore cannot be denied to anyone who are seeking it, except in a very limited situation as provided by the relevant treaties [11]. The human right to life is also considered "inherent". This is to be understood to mean that human beings have a right to life simply because they are human beings, irrespective of who they are such as their racial association or their nationalities. States must refrain from taking life, but also act to protect the loss of life. This is known as positive and negative obligations.

\subsection{The Right to Life under International Law}

The right to life forms a part of the larger scope of human rights in general [12]. The Universal Declaration of Human Rights which has become the guiding principles of human rights on the international plane, under Article 3 mentions that "[e]veryone has the right to life, liberty and security of person." This principle even though constitutes a soft law, has over the course of years "hardened' into hard binding law. This can be seen in the International Covenant on Civil and Political Rights 1966 (ICCPR). According to Article 6(1) of the Convention, it dictates that "[e]very human being has the inherent right to life. This right shall be protected by law. No one shall be arbitrarily deprived of his life."

Many other international conventions as well as the regional ones have repeated the same standings. These include the European Convention on Human Rights (Article 2), the Convention on the Rights of the Child (Article 6), the International Convention on the Protection of the Rights of All Migrant Workers and Members of Their Families (Article 11), the Convention on the Rights of Persons with Disabilities (Article 10), the African Charter on Human and Peoples' Rights (Article 4) and the American Convention on Human Rights (Article 4).

The concept of "inherent right to life" has been discussed by a lot of scholars to mean that this right flows from the existence of human being himself. The right to life of human beings are also closely related to his dignity. The preamble of the ICCPR made a mention that this right to life is "inalienable rights of all members of the human family", this is to mean that such right is so supreme that no states can deny it. 
According to the ICCPR's General Comment No. 6, regarding the application and scope of the Article 6 (right to life), it mentions that such right cannot be derogated even in time of public emergency that may threaten the life of the nation. This right requires states not to interpret it in restrictive, narrowed manner, but instead to interpret it in the broadest ways possible. States therefore are required to refrain from committing something that will deprive human life (negative obligation), but also to adopt positive measures by taking actions to prevent unnecessary loss of lives. Consequently, states have duty to protect life by doing everything within its abilities to preserve lives of everyone within its territory. The right to life is a jus cogens norms which has attained the status of custom under international law (Ramcharan, 1985). Therefore, states are prohibited from violating this right even in case of emergency. Malaysia must not push away these asylum seekers who are trying to land on its shores. Many international conventions have adopted this principle as part of their rules. These include major international covenants as well as regional ones as stated earlier.

\subsection{Application of the Right to Life in the Malaysian Context}

Malaysia is however not party to the core conventions of asylumseekers protection. Malaysia is not signatory to the core conventions of international refugee law which are the Convention Relating to the Status of Refugees (CRSR) and its protocol, the 1967 Protocol Relating to the Status of Refugees. This makes it harder to find the right laws to bind the country to respect the right to life of these seaborne asylum seekers.

Malaysia's international obligations in protecting the right to life can be found in either binding or non-binding treaties. The Universal Declaration of Human Rights (UDHR), under Article 3: provided specifically that "[e]veryone has the right to life, liberty and security of person." The International Covenant on Civil and Political Rights 1966 (ICCPR). Article 6(1): "Every human being has the inherent right to life. This right shall be protected by law. No one shall be arbitrarily deprived of his life."

Besides, it is to be noted that Malaysia is a party to a number of binding international conventions that have specific provisions that dealt with the right to life principle. This include Convention on the Rights of Persons with Disabilities (CRPD) and Convention on the Rights of the Child (CRC). Article 10 of the CRPD provides that "[s]tates Parties reaffirm that every human being has the inherent right to life." While Article 6 of CRC mentions that "[s]tates Parties recognize that every child has the inherent right to life.". The word 'every' is therefore brings this piece of law applicable to the asylum seekers as well. It is to be noted that Malaysia has not made any reservations vis-à-vis those particular provisions. It also has no interpretative declarations that altered the understanding of any of these provisions.

Malaysia is bound by the principles of customary international law. These principles are either exist in non-codified forms or codified versions such as those that have been incorporated into the international treaties. As discussed earlier, there are treaties that directly relevant to the right to life of the asylum-seekers at sea which Malaysia had ratified. These include the Convention on the Rights of Persons with Disabilities (CRPD) and Convention on the Rights of the Child (CRC). In order for a law to evolve into custom under international law, it has to reach certain level of state practices that are widespread enough. These practices as well as the existence of opinio juris will create a custom that binds all states except those that persistently objected to such rules in the first place.

The right to life is not just limited within international law's domain. Many national laws do incorporate this right as part of their laws. Malaysia is no exception. The Federal Constitution of Malaysia which is apex law of the country contains provision that requires the government to protect the right to life. Article 5(1) of the Constitution states that "[n]o person shall be deprived of his life or personal liberty save in accordance with law. In Suzana bt Md Aris v. DSP Ishak bin Hussain \& Ors [2011] 1 MLJ 107, the judge has given a generous interpretation of the provision mentioned in Articles 5 (1). In this case the court held that where a person in police custody is deprived of medical attention and assistance, he is deprived of his life while his liberty is being deprived by law in the case of a lawful arrest and detention.

Referring to India's jurisprudence which shared the same legal tradition as Malaysia, the Indian Supreme Court adopted this thinking in a series of cases which saw its full exposition in the landmark case of Maneka Gandhi, supra, which propounded the co-relation between Article 14 (Malaysian Article 8) and Article 21 (Malaysian Article 5) (the Indian provision however reads 'except according to procedure established by law') and later in the case of Frances Coralie v Union of India, AIR 1981 SC 746 at 752-753. In Frances Coralie's case, Bhagwati J speaking for the Indian Supreme Court expressly adopted the reasoning:

"Now what is the true scope and ambit of the right to life guaranteed under this Article? .... the attempt of the court should always be to expand the reach and ambit of the fundamental right rather than to attenuate its meaning and content .... Now obviously, the right to life enshrined in Art 21 cannot be restricted to mere animal existence. It means something much more than just physical survival .... Every limb or faculty through which life is enjoyed is thus protected by Art 21. And a fortiori, this would include the faculties of thinking and feeling."

In turn, the Court of Appeal of Malaysia in Sugumar Balakrishnan $v$ Pengarah Imigresen Negeri Sabah \& Anor [1998] 3 MLJ 289 adopted the Indian jurisprudence on the wide meaning of life and personal liberty in Article 21 and concluded (at page 305): 'In our judgment, the words "personal liberty" in Article 5(1) should be similarly interpreted. Any other approach to construction will necessarily produce an incongruous and absurd result. For, "life" are both equally dynamic concepts and should be treated in like fashion.'

While in the case of Tan Tek Seng v. Suruhanjaya Perkhidmatan Pendidik \& Anor, G Sri Ram JCA in its judgment stated that the word "life" in Article 5(1) shall be given a broad and liberal meaning. The right to life here is not restricted to the citizen but also applicable to non-citizen as well. This interpretation shows the opinion of a judge which consistent with the established international law jurisprudence. This important provision guarantees that human life must not be deprived unless it is allowed by the law in force. Due to the wordings of the provision, such constitutional guarantee is interpreted as not just restricted only to citizens of the country, but also extend to the non-citizens as well which includes asylum-seekers. Based on the cases earlier mentioned, this is arguably that the provision in the Federal Constitution of Malaysia specifically in Article 5(1) shall be given a broad and liberal meaning which include the right to life to asylum-seekers for instance.

The right to life is a part of fundamental human rights that requires strict protection from all states. As argued by Nordin, Malaysia's perspective on human rights is strongly influenced by Asian values, as compared to Western values that emphasized more on strong individual rights protection as opposed to rights of community [13]. However, as a part of an international community, Malaysia should not live in isolation. Sooner or later, it has to follow the standards expected from wider international community with regards to the human rights. The protection of asylum-seekers's right to life should not be seen as a burden as Malaysia has humanitarian responsibility and it is required by law.

\section{The Duty to Rescue}

As discussed earlier in the right to life's part, corollary to asylumseeker having the right to life while stranded at sea, will require action to be taken to protect this right. Thus, the duty to rescue is therefore invoked on his behalf. This duty to rescue has been an 
old practice tradition throughout generations, in that, it has become a customary practices that every state must not ignore. This duty is applicable either towards the shipmasters or the governments or both. On the part of the government, there is an explicit duty to provide for maritime search and rescue and to conduct necessary mission to recover those in danger at sea [14].

\subsection{Duty to Rescue under International Law}

\subsubsection{Duty to Render Assistance}

The UNCLOS, under the heading duty to render assistance of Article 98 explicitly provides for the duty to rescue. It uses the term "any person", which covers all human beings at sea which include asylum-seekers. This duty is applicable to the shipmasters of both the private ships or government-owned vessels [15]. It states that:

1. Every State shall require the master of a ship flying its flag, in so far as he can do so without serious danger to the ship, the crew or the passengers:

(a) to render assistance to any person found at sea in danger of being lost;

(b) to proceed with all possible speed to the rescue of persons in distress, if informed of their need of assistance, in so far as such action may reasonably be expected of him;

(c) after a collision, to render assistance to the other ship, its crew and its passengers and, where possible, to inform the other ship of the name of his own ship, its port of registry and the nearest port at which it will call.

Paragraph 2 of the same Article requires every coastal State to "promote the establishment, operation and maintenance of an adequate and effective search and rescue service regarding safety on and over the sea and, where circumstances so require, by way of mutual regional arrangements cooperate with neighbouring States for this purpose".

This duty on the government can also be seen in SOLAS Chapter $\mathrm{V}$, Regulation 7, which requires each State Party to "[e]nsure that necessary arrangements are made for distress communication and co-ordination in their area of responsibility and for the rescue of persons in distress at sea around its coasts. These arrangements shall include the establishment, operation and maintenance of such search and rescue facilities as are deemed practicable and necessary, having regard to the density of the seagoing traffic and the navigational dangers and shall, so far as possible, provide adequate means of locating and rescuing such persons"

Apart from the UNCLOS provision as above, the Safety of Life at Sea Convention (SOLAS), under Chapter V, Regulation 33 provides that:

\subsubsection{Application of the Duty to Rescue in Malaysia's Context}

The master of a ship at sea which is in a position to be able to provide assistance on receiving information from any source that persons are in distress at sea, is bound to proceed with all speed to their assistance, if possible informing them or the search and rescue service that the ship is doing so. This obligation to provide assistance applies regardless of the nationality or status of such persons or the circumstances in which they are found.

Rescue is an act that consists of the beginning and the ending. Under Chapter 1, Para. 1.3.2. of the International Convention on Maritime Search and Rescue 1979 (SAR Convention) defines rescue as "an operation to retrieve persons in distress, provide for their initial medical or other needs, and deliver them to a place of safety." This means that without completing this full cycle of action, the act done by the shipmaster is not considered completed.

\subsubsection{Duty to Bring to a Place of Safety}

Annex to the 1979 SAR Convention, paragraph 1.3.2 provide for the duty to bring the persons in distress to a place of safety. However, the concept of place of safety generally not clear and has not been defined clearly in any of the international conventions [16], however, based on the Guidelines on the Treatment of Persons Rescued at Sea [17]. It is explained by the guidelines that "[a] place of safety is a location where rescue operations are considered to terminate. It is also a place where the survivors' safety of life is no longer threatened and where their basic human needs (such as food, shelter and medical needs) can be met. Further, it is a place from which transportation arrangements can be made for the survivors' next or final destination".

A ship that is used for assisting the persons do not fall within the definition of place of safety. However, the ship can act as temporary place of safety, and this requires cooperation at government levels to find the most suitable place of safety for those people. The best place of safety is always at land, but it depends on caseby-case basis. Besides, survivors among asylum-seekers are not to be send to territories where their lives are in danger. This is known as the rule of non-refoulement [18].

\subsubsection{Duty to Allow for Disembarkation}

The disembarkation in territories where the lives and freedoms of those alleging a well-founded fear of persecution would be threatened must be avoided in the case of asylum-seekers and refugees rescued at sea [19]. The question of where to disembark the asylum-seekers saved at sea can be very controversial since state usually invokes its sovereignty in order to decide who can enter its territory and who cannot [20]. However, O'Brien posits that corollary to the duty to rescue, is the duty of the state in which the rescue takes place to allow the disembarkation of those saved on its territory [21]. Coppens therefore suggested that the closest port of any states should be the ideal place for the disembarkation [22].

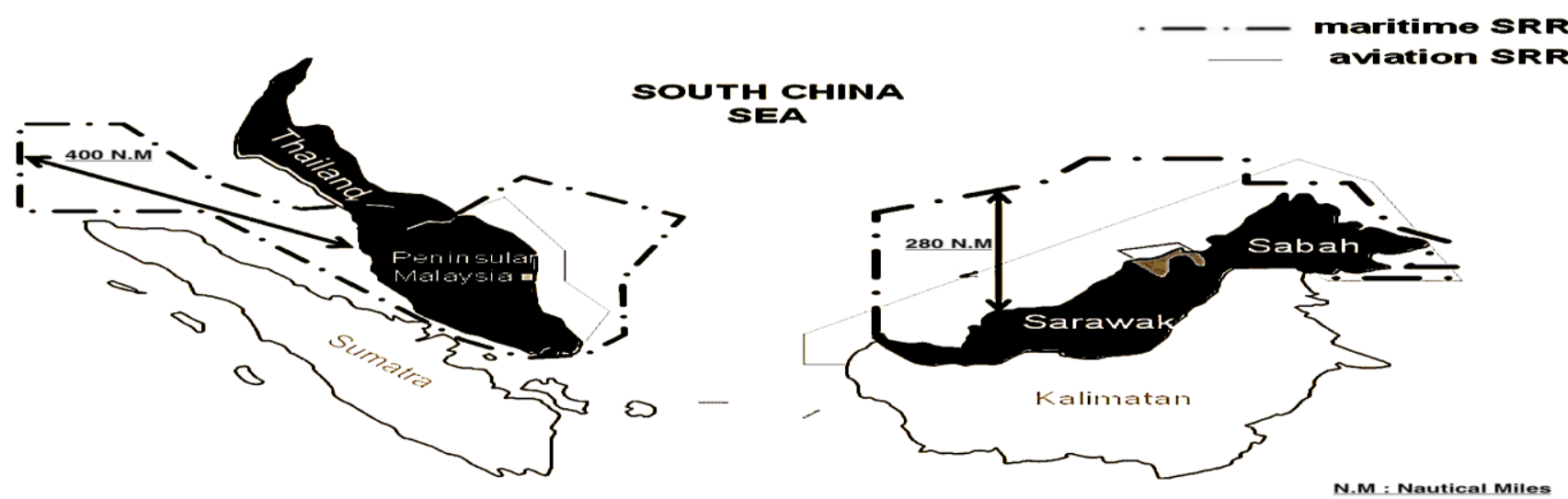

Fig. 1: Maritime Search and Rescue Region (SRR). 
It is to be noted that Malaysia is a party to the UNCLOS 1982 and SOLAS Convention 1974. However, Malaysia has not yet signed and ratified the SAR Convention 1979. Therefore, most of those duties and obligations as discussed earlier are also applicable to Malaysia.

Before we proceed with further discussion on Malaysia's duty to rescue asylum-seekers at sea, it is crucial for us to get an overview of the scope of maritime search and rescue areas being entrusted to the Agency. As can be observed in Figure 1, the area is divided between two regions of the country, the East Malaysia and the West Malaysia. Basically, in West Malaysia, the area covered the distance between the Straits of Malacca up to 400 nautical miles towards the Andaman Sea. While in East Malaysia, the area extended from the baselines of Sarawak to the middle of South China Sea which is within the Exclusive Economic Zone of Malaysia. On the Sabah's side, it covered some part of the Sulu Sea.

The main agency in Malaysia that has been given duty to conduct search and rescue at sea is this MMEA which also known as the "Coast Guard". The duty to rescue has been incorporated in Malaysian Maritime Enforcement Agency Act 2004 (Act 633). In Section 6(1)(b), one of the functions of the Agency is "to perform maritime search and rescue". The duty to conduct the rescue mission for persons in distress at sea is at the moment being solely entrusted to this Agency since 6 June 2006 under its specialized unit known as "Cawangan CARILAMAT dan Bantuan Bencana (CLBB)". On 13 August 2008, the National Search and Rescue Committee was restructured and appointed the Secretary of the National Security Council as the Chairman [23]. Nonetheless, other authorities such as the Navy and the Marine Police sometimes do conduct their own search and rescue if necessary.

The idea of having a Coast Guard was started on 21 April 1999 when a study was done to evaluate the nation's need of a single agency responsible for maritime enforcement. On 21 August 2002, the Malaysian Cabinet finally approved the establishment of the Agency. The vision of the MMEA is to become one of the best maritime enforcement agencies in the world. It has a mission to enforce the laws at sea as well as to save lives and property at sea [23]. This mission is done in order to maintain stability of the Malaysia's maritime zone. Section 3(2) of the Malaysian Maritime Enforcement Agency Act 2004 succintly explains the aim and purposes of the Agency's establishment. It states that:

the agency shall, subject to this act, be employed in the malaysian maritime Zone for the maintenance of law and order, the preservation of the peace, safety and security, the prevention and detection of crime, the apprehension and prosecution of offenders and the collection of security intelligence.

Apart from performing maritime search and rescue, this Agency also has other related functions. This can be seen under Section 6(1) which states that:

The functions of the agency shall be

(a) to enforce law and order under any federal law;

(b) to perform maritime search and rescue;

(c) to prevent and suppress the commission of an offence;

(d) to lend assistance in any criminal matters on a request by a foreign state as provided under the Mutual Assistance in Criminal Matters Act 2002 [Act 621];

(e) to carry out air and coastal surveillance;

(f) to provide platform and support services to any relevant agency;

(g) to establish and manage maritime institutions for the training of officers of the agency; and

(h) generally to perform any other duty for ensuring maritime safety and security or do all matters incidental thereto.

Section 6(2) of the Act provides for the specific locality in which the Agency shall exercise its power; that is within the Malaysian maritime zones. These zones are divided into the internal waters, territorial sea, continental shelf, exclusive economic zone and the malaysian fisheries waters and includes the air space over the Zone (Section 2). Section 7(2) of the Act granted very specific powers to the Agency which inter alia includes power to "stop, enter, board, inspect and search any place, structure, vessel or aircraft and to detain any vessel or aircraft" and "to expel any vessel which it has reason to believe to be detrimental to the interest of or to endanger the order and safety in the Malaysian maritime Zone".

The Agency, in its 2015 annual report document defined the maritime search and rescue as an act of searching, helping and rescuing human's life that was lost or at risk of being lost at sea during situation of distress while on voyage or on flight, regardless of the nationalities of the persons or their status or the conditions they are found at sea [23]. These wordings are apparently a repetition of the SOLAS Convention under Chapter V, Regulation 33 as discussed earlier in this article. Since mid-2006 until the end2015 , there were 1636 cases of distress at sea that were handled by the Agency. Unfortunately, the report did not provide for the breakdown of how many of these cases actually involved the asylum-seekers.

Nonetheless, given the functions and powers as granted by the Act, and the Agency's perfectly worded definition of what constitutes search and rescue, it was unfortunate to witness the event that was unfolded in May 2015 when the Agency reacted adversely against the Rohingya's asylum-seekers seeking a temporary refuge, leaving them stranded at sea for weeks [24]. This act was clearly in breach of not only the established rules of international law on the duty to rescue but also it contravened Section 6(1)(b) of the Malaysian Maritime Enforcement Agency Act 2004 which requires the Agency to conduct the maritime rescue.

\section{Suggestion and Concluding Remarks}

Saving lives at sea is a custom that must be honoured by every sovereign state. Malaysia's non-compliance with rules of international law concerning rescuing asylum-seekers lives at sea constitute a breach of its international obligation. The principle of Pacta Sunt Servanda must be duly observed and Malaysia must comply with the treaties that is has agreed to be bound to and perform them in good faith. Malaysia breached of its international obligations vis-a-vis duties to render assistance to persons in distress at sea will incur an international responsibility.

Human rights and the law of the sea are not usually discussed within the same breath. Despite the fact that the general rules in this area are made for the purpose of maintaining effective governance of sea areas. The law of the sea does have rules that specifically meant for the protection of human rights which is the duty to rescue. Malaysia is therefore required to provide humanitarian assistance on legal ground to persons on distress at sea, no matter who they are and circumstances that they are in. The facts that these asylum-seekers are considered as people in need of international protection, states therefore are obliged to provide protection regardless of their legal status under their domestic law. Whenever states have effective control over the asylum-seekers presence within their territory the protection of basic human rights is automatically obligatory upon the states.

The asylum-seekers who are stranded at sea shall be treated in accordance with the proper international standards. As a country which is relatively peaceful with decent quality of life, it is understandable why Malaysia is becoming a destination of choice for these asylum-seekers [25]. The article maintains that the international law has provided sufficient protections to these seaborne asylum-seekers that Malaysia must conform to. The right to life is one of them. By ratifying a few conventions which contained explicit provision on the protection of the right to life, Malaysia must be aware of its legal responsibility under international law. Besides, this right is a supreme right that surpasses all other rights 
and has attained the status of custom under international law. Therefore, Malaysia is bound by this rule.

It is, therefore, submitted that Malaysia is bound to abide by the established rules of international human rights law vis-à-vis the right to life. Additionally, Malaysia is also bound under international law of the sea to abide by the duty to rescue and to render assistance. It is suggested that Malaysia should initiate a revision of its national laws and policies regarding treatment of seaborne asylum-seekers stranded at sea, to be in line with Malaysia's international obligations. Besides, the Malaysian Maritime Enforcement Agency (MMEA) to stricly comply with the international standards of treatment of persons in distress at sea which includes the asylum-seekers.

\section{References}

[1] UNHCR (2018), Asylum-Seekers. Retrieved February 2018, 2018, from UNHCR: http://www.unhcr.org/en-my/asylum-seekers.html

[2] Phillips J (2011 January 14), Asylum seekers and refugees: what are the facts? BACKGROUND NOTE - Department of Parliamentary Services. Canberra, Australia.

[3] Kassim, A. (2009). Filipino Refugees in Sabah: State Responses, Public Stereotypes and the Dilemma Over Their Future. Southeast Asian Studies 52-88.

[4] Erlanger S (1990 April 17), MALAYSIA ACCUSED ON BOAT PEOPLE. Retrieved February 20, 2018, from The New York Times: http://www.nytimes.com/1990/04/17/world/malaysiaaccused-on-boat-people.html

[5] Klein N (2014), Assessing Australia's Push Back The Boats Policy Under International Law: Legality And Accountability For Maritime Interceptions Of Irregular Migrants. Melbourne Journal of International Law (15), 414.

[6] UNHCR. (2015 May 2015), Joint Statement by UNHCR, OHCHR, IOM and SRSG for Migration and Development: Search and rescue at sea, disembarkation, and protection of the human rights of refugees and migrants now imperative to save lives in the Bay of Bengal and Andaman Sea. Retrieved February 20, 2018, from UNHCR: http://www.unhcr.org/555aee739.html

[7] Human Rights Watch (2015 May 14), Southeast Asia: End Rohingya Boat Pushbacks - Thailand, Malaysia, Indonesia Should Act Urgently to Save Lives. Retrieved February 20, 2018, from Human Rights Watch: https://www.hrw.org/news/2015/05/14/southeast-asia-endrohingya-boat-pushbacks.

[8] UNHCR (2018), UNHCR thanks Indonesia and Malaysia for rescue and disembarkation of Rohingya refugees, calls on countries in the region to comply with maritime search and rescue obligations. Retrieved from United Nations High Commissioner for Refugees (UNHCR): http://www.unhcr.org/enmy/news/press/2018/5/5ae81d624/unhcr-thanks-indonesiamalaysia-rescue-disembarkation-rohingya-refugees.html .

[9] Malaysian Maritime Enforcement Agency (2015), Laporan Tahunan Maritim Malaysia - Laporan Tahunan 2015 (Annual Report 2015). Retrieved from Malaysian Maritime Enforcement Agency (MMEA): https://www.mmea.gov.my/artikel/Laporan_Tahunan/APMM_Lapo ranTahunan_2015.pdf

[10] Worster WT (2014), The Contemporary International Law Status of the Right to Receive Asylum. International Journal of Refugee Law 26(4), 477-499.

[11] Edwards A (2005 January 1), Human Rights, Refugees, and The Right 'To Enjoy' Asylum. International Journal of Refugee Law $17(2), 293-330$.

[12] Basir SM (2011), Right to Development as a Human Right: A Challenge to Malaysia. In K. A. Mokhtar, Constitutional Law and Human Rights in Malaysia: Selected Issues 333. Kuala Lumpur: IIUM Press.

[13] Nordin R (2010), Malaysian Perspective on Human Rights Malaysian Journal of Law and Society (JUUM) 17-33.

[14] Papanicolopulu I (2016) The duty to rescue at sea, in peacetime and in war: A general overview. International Review of the Red Cross 491-514.

[15] Severance AA (2006), The Duty to Render Assistance in the Satellite Age. California Western International Law Journal, 377400.
[16] Moen AE (2010), For Those in Peril on the Sea: Search and Rescue under the Law of the Sea Convention. Ocean Yearbook Online 377

[17] International Maritime Organization (2004 May 20), GUIDELINES ON THE TREATMENT OF PERSONS RESCUED AT SEA. Retrieved from IMO.ORG: http://www.imo.org/en/OurWork/Facilitation/personsrescued/Docu ments/MSC.167(78).pdf.

[18] Allain J (2001), The jus cogens Nature of non-refoulement. International Journal of Refugee Law 533-558.

[19] Gombeer K (2017), Human Rights Adrift? Enabling the Disembarkation of Migrants to a Place of Safety in the Mediterranean. Irish Yearbook of International Law 9.

[20] Ratcovich M (2015), The Concept of 'Place of Safety': Yet Another Self-Contained Maritime Rule or a Sustainable Solution to the Ever-Controversial Question of Where to Disembark Migrants Rescued at Sea? Australian Year Book of International Law 1-52.

[21] O'Brien KS (2011), Refugees on the High Seas: International Refugee Law Solutions to a Law of the Sea Problem. Goettingen Journal of International Law 715-732.

[22] Coppens J \& Somers E (2010), Towards New Rules on Disembarkation of Persons Rescued at Sea? The International Journal of Marine and Coastal Law 377 - 403.

[23] Malaysian Maritime Enforcement Agency (MMEA) (2018 April 3), MEDIA RELEASE: BOAT CARRYING ROHINGYA WHO FLED FROM MYANMAR LANDED IN LANGKAWI. Retrieved from Malaysian Maritime Enforcement Agency (MMEA): https://www.mmea.gov.my/artikel/Siaran_Media/2018/PR_ROHIN GYA 3.4.18.

[24] Murdoch L (2015 May 13), 'Some are already dead': Rohingya Muslims stranded at sea by Indonesia and Malaysia. Retrieved from The Sydney Morning Herald: https://www.smh.com.au/world/some-are-already-dead-rohingyamuslims-stranded-at-sea-by-indonesia-and-malaysia-20150513gh0f8j.html .

[25] Basir SM (2014), Sustainable Development In Malaysia: The Way Forward And Challenges In The Modern Era. Brawijaya Law Journal 4 . 